Whitman, gasped into poor Horace Traubel's solicitous ear, and too horrible, almost, to be remembered in a Christian land" ("Introduction," Essays by fames Huneker [New York: Charles Scribner's Sons, 1929], xiv). As for Whitman's use of the word "shit," one might adduce Ellen O'Connor Calder's statement that "no man ever lived who loathed coarseness and vulgarity in speech more than he" (quoted in David S. Reynolds, Walt Whitman's America: A Cultural Biography [New York: Alfred A. Knopf, 1995], 203). On the other hand, Traubel does record Whitman using the word.

\title{
WALTER DE LA MARE AND WALT WHITMAN: A BIBLIOGRAPHICAL NOTE
}

Scott Giantvalley, in his Walt Whitman, 1838-1939: A Reference Guide (Boston: G. K. Hall, 1981), cites the following essay under the year 1915: "[de la Mare, Walter.] 'Drum-Taps.' Times Literary Supplement (London) (1 April), 105-6" (item 31, p. 248). Giantvalley does not mention the reprinting of this essay in the Chatto \& Windus edition of Drum-Taps later in 1915. Joel Myerson, in Walt Whitman: A Descriptive Bibliography (Pittsburgh: University of Pittsburgh Press, 1993), indicates that the Chatto \& Windus Drum-Taps reprints the introductory essay from "the 1 April 1915 Times Literary Supplement [by Walter de la Mare]" (151). Giantvalley's and Myerson's brackets indicate that the TLS article, like its reprinting in the Chatto \& Windus Drum-Taps, was unsigned. There is no indication what source Giantvalley and Myerson used to identify de la Mare as the author.

Several years ago, I acquired from a London bookseller a copy of the Chatto \& Windus Drum-Taps, in which was tucked a typewritten letter written on London Times Literary Supplement stationery by Fay Hall, Editor's Secretary, to one L. A. Wallrich, Esq., Thomastown House, Edenderry, Co. Offaly, Ireland:

\section{March 1965.}

Dear Mr. Wallrich,

Thank you for your letter of 8 March.

In the circumstances there is no objection to your knowing that the writer of the article on Drum-Taps was Walter de la Mare.

Yours sincerely,

Fay Hall

Editor's Secretary

This letter provides definitive evidence that de la Mare (1873-1956) was indeed the author of the essay "Drum-Taps" and that, as late as 1965, the identity of the author was still something of a mystery. 